\title{
トマトプラグ苗の側面接触定植は保水シート耕における活着を改善し 二段栽培の生産性を向上させる
}

\author{
中野明正 ${ }^{* 1}$ ） 江口陽子 ${ }^{2)} \cdot$ 酒井浩伸 $^{2)} \cdot$ 趙鉄軍 $^{1)} \cdot$ 並崎宏美 $^{* * 3)}$ \\ 1）農業・食品産業技術総合研究機構 野菜花き部門 \\ 2）鈴与商事株式会社 \\ 3）熊本県農業研究センター
}

要 旨: トマトの養液栽培を保水シート耕で行う場合, 定植時にプラグ苗の底面を保水シートに接触させ る慣行法よりも, 側面を保水シートに接触させる側面接触定植の方が, その後にプラグ苗から展開する根量 が増加した。この知見をトマトの二段栽培に適用して生産性（収量および品質）を評価した．生産围場で評 価した場合でも, 側面接触定植区の方が最終的には根の乾物重が $14 \%$ 増加し, 着果率も平均で $42 \%$ 改善し, 生産物の果実糖度も $15 \%$ 有意に増加した。

キーワード：定植, 二段栽培, 不定根, プラグ苗, 保水シート耕.

\begin{abstract}
Transplanting by side contact method of plug seeding increases the productivity of two truss tomato on wet sheet culture by improving the initial taking root : Akimasa $\mathrm{NAKANO}^{1}$, , Yoko EGUCHI ${ }^{2}$, Hironobu $\mathrm{SAKAI}^{2}$, Tiejun ZHAO ${ }^{1)}$ and Hiromi NAMISAKI ${ }^{3)}\left({ }^{1)}\right.$ National Agriculture and Food Research Organization, Institute of Vegetable and Floriculture Science, ${ }^{2}$ Suzuyo Research Institute Co.,LTD. ${ }^{3}$ Kumamoto agriculture research center.)

Abstract : Transplanting by side contact method of plug seeding increased the root development after transplanting on wet sheet culture compared to conventional bottom contact transplanting. This method was applied to field experiment of two truss cropping system of tomato. As a result, transplanting by side contact method of plug seeding increased the rate of fruits setting by $42 \%$, the root dry weight by $14 \%$ finally and sugar content of tomato fruits by $15 \%$ compared to conventional transplanting.
\end{abstract}

Keywords : Adventitious root, Plug seedling, Transplanting, Two truss tomato, Wet sheet culture.

\section{緒言}

トマトの安定多収生産のひとつの流れとして低段・ 多回転栽培がある。特に高温期执いては, 長期多段栽 培よりも定植時期によっては樹勢の衰えを回避しやす いので, 生産が安定化できる可能性がある。 今後, 夏 季の高温抑制技術等が開発され, さらに多収化が進む と考えられ，長期多段栽培のみだけではなく，低段密 植栽培でも総合的に高品質多収をねらえる可能性があ る(中野, 2016).

高温期の多収化をめざして, 高温期に適する品種選 択を実施した研究事例もあるが (中野，2017），高温期 などストレスが負荷されやすい環境下で安定的な生産を 可能とする栽培方法の改善も必要である. 実際, 播種日 を異にした収量解析の結果からは, 夏季に苗の定植を 行う場合, 収量が低下することが示されている(小林, 1997, 竹川·土屋, 2010). 要因についてはいくつか可 能性が考えられるが, 高温環境における蒸散要求量に 定植直後の根が十分適応できていないため, 生長点(花
芽)などが障害を受けることが考えられる，特に養液栽 培の方式のひとつである保水シート耕は, 定植時にスト レスが負荷されやすいと考えられる。 つまり, 保水シー 卜耕は毛管水耕と湛液水耕の折衷型であり, 根は湿っ たシート上に発達して, 定植後 1 週間程度で, 先端は 液貯留部に到達するような栽培法であり（渡辺，2006）, 栽培の開始は, プラグ苗を直接湿潤なシート上に置床す るだけであるので(第 1 図), 作業が簡便である反面, 定植後にプラグ苗の表面の根が直接外気に触れるよう な手法であるため, 通常の土耕やロックウールに定植す る以上に, 根系にストレスが負荷されると考えられる.

そこで, 本研究では, 保水シート耕における苗の活 着の改善を目的として, 定植方法を検討した，通常は， プラグ苗の底面を保水シートに接触させるような方法 をとるが，改良法として接触面積を増加させるように 側面を保水シートに密着させるように定植し, その効 果を評価した，実際，このような手法で発根の促進が 確認されたため, 生産戋場に扔いてトマトの二段栽培 において収量および品質に与える影響を評価した。 


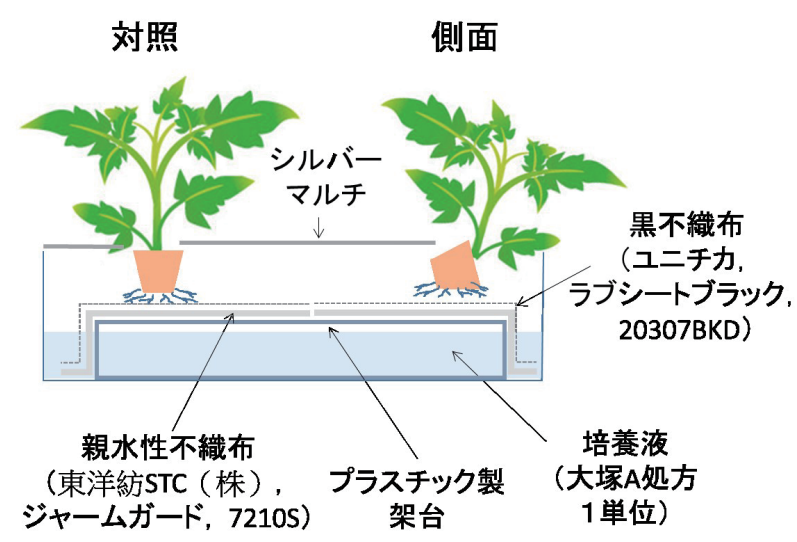

第 1 図保水シート耕を模した発根評価装置と定植法の模式図,

\section{材料及び方法}

\section{1. セル苗の定植方法が保水シート上における根の発達 に及ぼす影響評価}

育苗は, 人工光型育苗装置 (苗テラス, 三菱樹脂ア グリドリーム) を用いて行った。実験には“桃太郎ヨー ク’ (タキイ種苗) および ‘エンデバー’ (Rijk Zwaan 社) を使用した. 育苗は 72 穴のプラグ苗トレイ（セルトレー $\mathrm{AP}$, 東罐興業) を用い, 各セルに育苗用培養土 (種培 土 1 号，スミリン）を充填し，2016 年 4 月 19 日に 1 セ ル当たり 1 粒を播種した。トレイを播種後 3 日間催芽 器 $\left(28^{\circ} \mathrm{C}\right.$ 一定 $)$ に入れた後, 人工光型育苗装置に移動し, 蛍光灯は 3 波長系昼白色 Hf 蛍光灯 (FHF32EX-N-H, パナソニック）を用い栽培棚一段当たり 6 本とした。明 期 16 時間, 暗期 8 時間で 5 月 13 日まで育苗を行った（育 苗期間 21 日). 培養液は, $1 \mathrm{~L}$ 当たりハイテンポ $\mathrm{Cu}$ (住 友化学) $2.93 \mathrm{~mL}$ とハイテンポ $\mathrm{Ar}$ (住友化学) $0.98 \mathrm{~mL}$ を溶解したものを用い, EC $1.6 \mathrm{dS} \mathrm{m}{ }^{-1}$, pH5.9 (N-P-K = 5.9-1.1-2.4 $\left.\mathrm{me} \mathrm{L}^{-1}\right)$ とした. 潅水は 1 日 1 回 10 分間 $(8$ 時から 8 時 10 分まで), セルトレイ底面から $30 \mathrm{~mm}$ 程 度の高さまで培養液が満たされる状態とした。 その後, 重力により自然排水されるしくみである. 人工光型育 苗装置内の気温は毎日 0 時〜 8 時 (暗期) は $18^{\circ} \mathrm{C}, 8$ 時 〜 24 時 (明期) は $25^{\circ} \mathrm{C}$ とた. 人工光型育苗装置内の $\mathrm{CO}_{2}$ 濃度は $1000 \mathrm{ppm}$ とした。

その後, 上記条件で育苗した苗を, 太陽光型植物工 場 (農研機構, 野菜花き研究部門, つくば) 内の北育苗 区画に設置した保水シート耕を模した発根評価装置 (第 1 図) に置床し初期の生育を評価した。 プラグ苗か らの発根を評価するため, また, 次に述べる実際に保 水シート耕での結果と比較できるように, 保水性のあ る不織布 (東洋紡, ジャームガード, $7210 \mathrm{~S}$, 厚さ 2 $\mathrm{mm}$, 目付 $0.11 \mathrm{~g} \mathrm{~cm}^{-3}$ ) 上に黒不織布 (ユニチカ, ラブ シートブラック, $20307 \mathrm{BKD}$, 厚さ $0.13 \mathrm{~mm}$, 透水率 85\%, 遮光率 75\%）を敷設した構造とした。両布は培
養液に浸されているため, 根への養液の供給が充分行 われると考えられ，また，苗の周辺はシルバーマルチ で遮光したため, 処理期間中に根が乾燥するようなこ とはなかった。

対照区は通常のプラグ苗の置床方法であり，プラグ 苗の底面が保水シートに接するように定植した（第 1 図)，側面接触定植区は，接触面積を増加させるように 側面で保水シートに接触させ定植した，対照区と側面 接触定植区がそれぞれ保水シートに接触する面積は 4 $\mathrm{cm}^{2}$ および $11 \mathrm{~cm}^{2}$ であり, 側面接触定植区の方が大き かった. 対照区の苗は10日程度は自立可能と判断し, 誘引は行わなかった。側面接触定植区についても, 地 上部の頂芽は定植後 1 日でほぼ地面と垂直に上を向き その後実験期間中は自立したため誘引は必要でなかっ た.

11 日後の，同年 5 月 24 日に実験を終了し，それぞれ の処理区において発根状態を評価するとともに，地上 部の苗の生育量も合わせて評価した。根の評価につい てはWinRhizo (Regent Instruments Inc.) を用いて行い, 総根長および根の平均直径を計測した。

\section{2. 生産圃場における評価}

(1) 栽培条件

生産現場においても，対照区および側面接触定植区 を設けてトマトの生産性に与える影響を評価した。育 苗については 128 穴のセルトレーを用い, 前述に準じ て実施し,2016 年 7 月 8 日に“桃太郎ヨーク”を播種し, 同年 8 月 2 日に, 広さ $275 \mathrm{~m}^{2}$ (縦 $25 \mathrm{~m} \times$ 横 $11 \mathrm{~m}$ ) の区 画に幅 $30 \mathrm{~cm}$ の保水シート耕ベッドを 9 嘼配置した. その一部である 1 列 $25 \mathrm{~m}$ を 1 処理区として, 上記 2 処 理区の苗を株間 $8 \mathrm{~cm}$ で定植した（栽植密度 10.6 株 $\mathrm{m}^{-2}$ ). 二段栽培として, 花房には適宜植物ホルモン（ト マトトーン, 日産化学) を散布した。収穫開始は 9 月 20 日であり収穫終了は 10 月 13 日であった。 EC1.5 $\mathrm{dSm}^{-1}$ の園試処方養液を給液した。

栽培期間中の日平均気温および日平均湿度は, それ ぞれ, $26.6 \pm 4.4^{\circ} \mathrm{C}$ (平均值 \pm 標準偏差), $79 \pm 16 \%$ (平 均值 \pm 標準偏差) であり。地上部の環境制御としては 換気や遮光などを実施して, トマト栽培に適する環境 を維持できたと考えられた。

\section{(2) 生育調査等}

前述の処理列の中から調査株として 10 株を選定し た。初期の生育状況を評価するために花数および着果 率の調査を行った. 収穫開始後は概ね 2 日に 1 度収穫 を行い, 収量および糖度を非破壊で測定した。 また, 障害果の発生については, 収穫時の各処理区の栽培列 全体 (323 株) の収穫果数との障害果 (尻腐れ果および 裂果) の発生数から計算した。 
中野ら / 根の研究 (Root Research) 27 (1) : 5-9 (2018)

第 1 表 定植法が, 定植後の苗の生育および根の乾物, 長さおよび太さに与える影響.

\begin{tabular}{|c|c|c|c|c|c|c|c|c|c|}
\hline \multirow{2}{*}{ 品種 } & \multirow{2}{*}{ 定植法 } & \multirow{2}{*}{$\begin{array}{l}\text { 地上部 } \\
\text { 乾物重 } \\
\left(\mathrm{g} \text { 株 }{ }^{-1}\right)\end{array}$} & \multicolumn{2}{|c|}{$\begin{array}{c}\text { 根部 } \\
\text { 乾物重 }\end{array}$} & \multirow[t]{2}{*}{$\mathrm{T} / \mathrm{R}$} & \multicolumn{2}{|c|}{ 総根長 } & \multicolumn{2}{|c|}{ 平均根直径 } \\
\hline & & & $\begin{array}{c}\text { 外 } \\
\left(\mathrm{g} \text { 株 }^{-1}\right)\end{array}$ & $\begin{array}{c}\text { 内 } \\
\left(\mathrm{g} \text { 株 }{ }^{-1}\right)\end{array}$ & & \multicolumn{2}{|c|}{$\left(\mathrm{m}\right.$ 株 $\left.{ }^{-1}\right)$} & \multicolumn{2}{|c|}{$(\mathrm{mm})$} \\
\hline \multirow{4}{*}{ 桃太郎ヨーク } & 対照 & 6.1 & 0.137 & 0.171 & 19.9 & 14.3 & 17.8 & 0.43 & 0.39 \\
\hline & 側面 & 5.4 & 0.186 & 0.150 & 16.0 & 18.0 & 19.0 & 0.44 & 0.35 \\
\hline & 側面 / 対照 & 0.88 & 1.35 & 0.88 & 0.80 & 1.25 & 1.07 & 1.02 & 0.88 \\
\hline & & $*$ & ns & ns & $*$ & $*$ & ns & ns & ns \\
\hline \multirow{4}{*}{ エンデバー } & 対照 & 6.8 & 0.183 & 0.263 & 15.2 & 15.9 & 20.18 & 0.46 & 0.43 \\
\hline & 側面 & 5.9 & 0.229 & 0.214 & 13.4 & 19.0 & 18.58 & 0.47 & 0.40 \\
\hline & 側面 / 対照 & 0.88 & 1.25 & 0.82 & 0.88 & 1.19 & 0.92 & 1.00 & 0.93 \\
\hline & & ns & ns & $*$ & $\mathrm{~ns}$ & $\mathrm{~ns}$ & $*$ & $\mathrm{~ns}$ & ns \\
\hline
\end{tabular}

*:5\%の危険率で有意差あり, ns: 有意差なし $(\mathrm{n}=4)$, Student の $\mathrm{t}$ 検定.

内：育苗培養土内に存在した根. 外：保水シート上に置床後, シート上に展開した根。

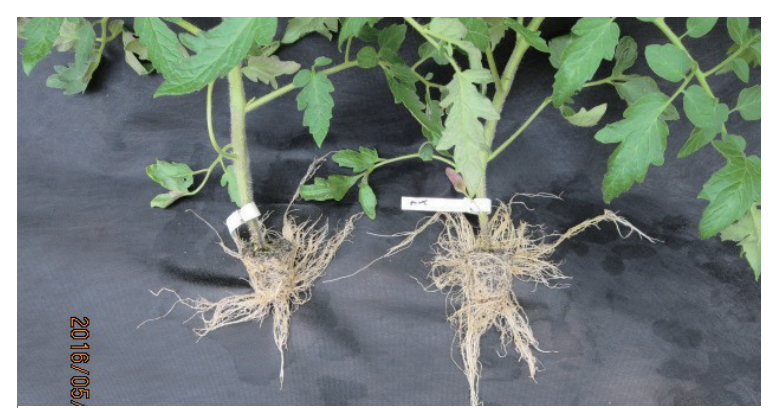

対照 側面

第 2 図 定植後 11 日目の発根の状態の差異.

栽培終了時に，それぞれの区について 12 株ずつ乾物 重を測定した，生産現場で使用されている装置の都合 上, 根は複雑に絡み合っているので, 株毎の切り分け が困難であり, 根については便宜上 4 株まとめてサン プリングした。根の区切りは株と株の中間地点とした。 根および地上部は採取後 1 ケ月程度かけて風乾し乾物 重を測定した．根の乾物重については 4 株分であるの で，4で除した值を株あたりの乾物重とした。

\section{結果}

\section{1. 根系の評価}

プラグ苗を側面接触定植することにより地上部の生 育は抑制され，プラグ苗から展開する根の量（外）が 増加する傾向が認められた (第 2 図, 第 1 表). 根長に ついては，“桃太郎ヨーク’ で有意に $25 \%$ 増加した。 こ れは ‘エンデバー’でも同様の傾向であった，結果的 に ‘桃太郎ヨーク’では T/R 比が側面接触定植により 有意に低下した。根の直径についての有意な差は認め られなかった。

\section{2. 生産現場における生産性の改善}

（1）着果率と果実収量および品質

定植方法を側面接触定植にすることで，第一花房，
第二花房とも花数には有意な差は認められなかった. 一方, 着果率は対照区に比べ側面接触定植区では第一 花房で 1.3 倍，第二花房で 1.6 倍高くなった（第 2 表）. また，果実収量については，側面接触定植によって有 意差は認められなかったが増加傾向が認められた，果 実糖度についは第一果房に抏いて，側面接触定植が対 照区に比べ15\%有意に高まる結果が示された(第3図).

\section{（2）栽培終了時の地上部および地下部乾物重}

側面接触定植により, 茎葉および地下部の乾物量は 増加する傾向にあった，特に，側面接触定植区の根部 乾物重は対照区に比べ有意に $14 \%$ 増加した（第 3 表）.

\section{(3) 障害果率}

尻腐れ果の発生は両処理区とも認められなかったが, 裂果率は側面接触定植で有意に増加した (第 4 図)。す なわち, 最終的な裂果率が，第一果房では平均で対照 区が $3.8 \%$ なのに対して，側面接触定植区では $8.4 \%$, 第二果房では，対照区が $11.2 \%$ なに対して，側面接 触定植区で $20.0 \%$ となり，概ね対照区の倍の裂果発生 率となった。

\section{考察}

保水シート耕は，株元の根が空気中に露出するため, 単純な湛液水耕よりも酸素欠乏の危険が小さいとされ る。実際，宮崎県のトマト生産農家では，このような生 産方法を導入して経営をしていて(渡辺，2006), 安定 的な運営が図られている。一方で, 夏季の高温など環 境条件が悪い時期での定植においては，収量の低下が 問題となっている。これについては，水分ストレスが 負荷されやすい状況であると考えられた，つまり，定 植直後は十分に根が発達していないため，花芽などが ストレスを受けて形成されにくくなる可能性も考えられ た。一段栽培においても, 着果数は花芽分化期の高温 条件により減少する。桃太郎では 8 月播種，八ウス桃 太郎では 8,9 月の高気温時の播種では，1 株当たり 3.5 果を下回ることがあった（小林，1997）。今回検証した 
第 2 表 側面接触定植が花数および着果率に及ぼす影響.

\begin{tabular}{ccccccc}
\hline \multirow{2}{*}{ 定植法 } & \multicolumn{2}{c}{ 花数 } & & \multicolumn{2}{c}{ 着果率 $(\%)$} \\
\cline { 2 - 3 } \cline { 5 - 6 } \cline { 5 - 6 } 第一花房 & 第二花房 & & & 第一花房 & 第二花房 \\
\hline 対照 & 4.4 & 5.2 & & 60 & 36 \\
側面 & 4.3 & 4.5 & & 80 & 57 \\
\hline 側面/対照 & 0.98 & 0.87 & & 1.33 & 1.58 \\
& $n s$ & $n s$ & & $*$ & $*$
\end{tabular}

*:5\%の危険率で有意差あり, ns: 有意差なし $(\mathrm{n}=10)$, Student の $\mathrm{t}$ 検定.

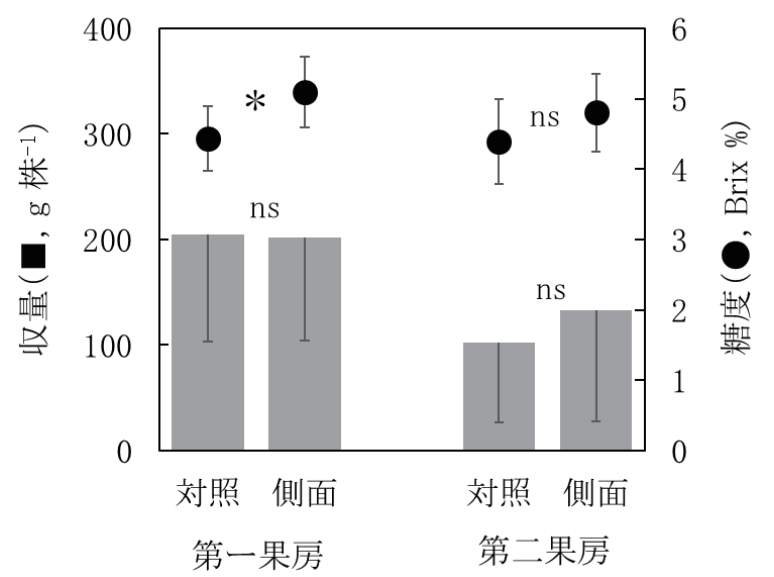

第 3 図 側面接触定植がトマト二段栽培の収量および糖度に与 える影響.

*:5\%の危険率で有意差あり, ns: 有意差なし $(\mathrm{n}=10)$, Student $の \mathrm{t}$ 検定．縦棒は，標準偏差を示す。

側面接触定植においては，速やかに新たな側根または 不定根が発生することにより活着が良好であったと考 えらえる. 特に, 着果率が側面接触定植区で増加して 抢り，側面接触定植により活着時に発生しやすい水分 ストレスを緩和できた可能性がある(第 2 表)。一般的 に保水シート耕で直接定植される 21 日苗は, 概敉第一 花房が分化しており, 定植直後は第 2 花房分化期あた りと想定され，今回対象とした二段栽培に扔いては, 定植後 10 日程度は充実した花器官の形成において重 要な時期になると考えられる. その後の生育も側面接 触定植で旺盛であり (第 3 表), 活着が側面接触定植に より改善されたことを示唆している。 今回の側面接触 定植では，主茎が曲がるため，それにより基部にオー キシンが蓄積し, 不定根の発生が誘導された可能性が ある.メカニズムについては今後解明する必要がある.

物質生産性については側面接触定植が優れた，有意 な差は認められなかったが, 総生産量 (茎葉と根の合 計量）は対照区に比べ側面接触定植区で増加する傾向 にあり，根の乾物重に扔いては有意に $14 \%$ 増加してお
第 3 表 側面接触定植が栽培終了時の地上部および地下部の 乾物重に及ぼす影響。

\begin{tabular}{ccc}
\hline \multirow{2}{*}{ 定植法 } & \multicolumn{2}{c}{ 乾物重 $\left(\mathrm{g}\right.$ 株 $\left.^{-1}\right)$} \\
\cline { 2 - 3 } & 茎葉 & 根 \\
\hline 対照 & 24.1 & 10.4 \\
側面 & 28.6 & 11.9 \\
\hline 側面/対照 & 1.19 & 1.14 \\
& $\mathrm{~ns}$ & $*$ \\
\hline
\end{tabular}

*:5\%の危険率で有意差あり, ns: 有意差なし，

地上部 $(\mathrm{n}=12)$, 根部 $(\mathrm{n}=3)$, Student $の \mathrm{t}$ 検定.

※根はつながっているため, 株毎の切り分けが困難であり, 便宜上 4 株まとめて測定して，4で除した值を，株あたりの 根乾物重とした。

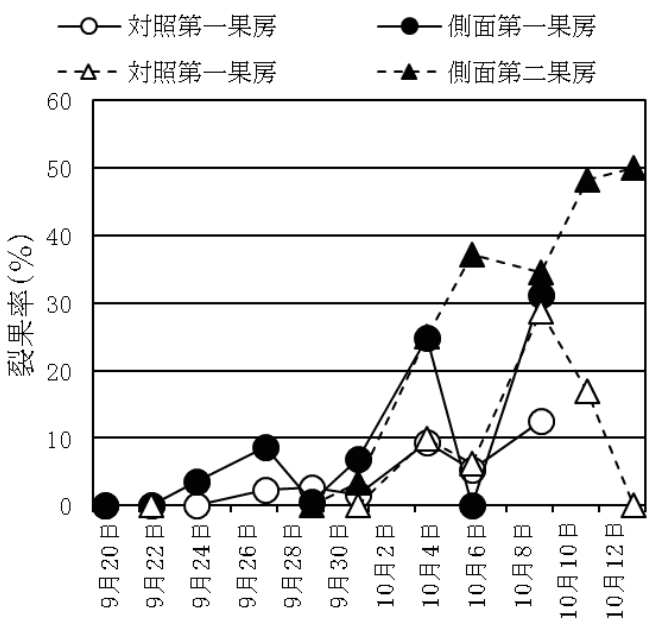

第 4 図＼cjkstart異なる定植法に打ける裂果率の推移. 収穫時の各処理区の栽培列全体 (323 株) の収穫果数と の障害果 (尻腐れ果および裂果) の発生数から計算した。

り(第 3 表), 定植時の活着の促進がその後の光合成量 の増加にも寄与していることを示唆している，また，果 実の内容成分の評価指標である糖度が側面接触定植で 増加しており（第 3 図），良好な活着による初期の葉面 積の速やかな拡大が，株あたりの光合成量を増大させ ることにより，生産量㧍よび品質の双方を向上させる 可能性が示唆された，根の活性の改善が卜マト果実を 増加させる報告がある（佐々木ら，2013）。これは長期 多段栽培の結果であり果実と根の同化産物の奪い合い を避けることが果実糖度の上昇に寄与しているとされ ている。 今回は低段密植栽培の結果であるが, 根量の 増加が認められており, 根の活性化が果実品質の向上 に結びつく可能性を示唆する類似の結果である，地上 部の生育も旺盛になり蒸散が盛んになった結果, 総体 的に水ストレスが負荷され，果実品質が向上した可能 性も考えられる。

一方で，裂果は側面接触定植により有意に増加した (第 4 図)。これは，対照区に比べ側面接触定植区で根 の生育が良好であり, 生育自体が旺盛になり, 吸水力 
が強くなりすぎた結果と考えられる。このような裂果に ついては, 緑熟で収穫（早めに収穫）して回避できる可 能性があるほか (中川ら，2016）, ホルクロルフェニュ ロン（フルメット液剤，協和発酵バイオ）など，ホルモ ン剤の散布で，発生を軽減できる可能性もある(飛川・ 久保，2012）。今後，生産現場でもこれらの処理を採用 して, 活着を改善したことによる旺盛な生育に伴う弊 害を回避して，多収を維持できる可能性がある。

以上，保水シート耕に扔いては，側面接触定植する ことにより初期の根長の伸びが大きく根の展開が促進 されたといえる。これは着果率の増加にも寄与し, 収 量および糖度の向上に寄与する可能性が示された。 マトの場合固定された光合成同化産物は，浸透圧や水 分ストレスによって果実に糖を集積するか，果実肥大 に寄与するか分配を異にする（斎藤ら，2006）。つまり， ストレス負荷により果実収量は低下するが，果実糖度 は上昇する。一般にこれはトレードオフの関係にあると 言われている (中野, 2017). 第 3 図に見られるように, 果実収量と糖度の積はいずれも, 側面接触定植区の方 が対照区に比べ大となる可能性があり, 環境制御を適 切に実施すれば，側面接触定植で多収になる可能性も あると考えられた。このような結果からも定植法を改善 することによる初期の側根または不定根の発生誘導が, 活着を促進し，夏季の高温，乾燥，冬の低温など，不
良環境下において，生産性を向上させる手法のひとつ となる可能性がある。

\section{引用文献}

小林尚司 1997. 養液栽培によるトマトの一段どり栽培に関する 研究 (第1 報) - 播種時期別の生育と果実収量. 農業施設 27 : 199-206.

中川卓也, 大道紀子, 淨閑正史, 塚越覚, 北条雅章, 丸尾達 2016. 貯 蔵温度が緑熟期トマトの追熟抢よび果実品質におよぼす影響. 園学研 15(別1): 118.

中野明正 2016. 日本農業の現状と植物工場の展開. 電学誌 136: 340-343.

中野明正 2017. 高品質安定多収生産をめざすトマト施設生産技 術の現状と展望. 農業および園芸 92: 321-331.

斎藤岳士, 福田直也, 西村繁夫 2006. 塩ストレス, 栽植密度ならび に果房直下の側枝がNFT 栽培トマトの収量および糖度に及ほ す影響. 園学研 5: 415-419.

佐々木英和, 河崎靖, 安場健一郎, 鈴木克己, 高市益行 2013. 八イ ワイヤー誘引栽培したトマトの主茎基部側枝が果実の糖度と 収量におよぼす影響. 野菜茶業研究所研究報告 12: 1-6.

竹川昌宏, 土屋和 2010 . トマトの3段どり養液栽培に抢ける周年 栽培体系モデル.兵庫農技総七研報 58: 1-7。

飛川光治, 久保紀子 2012. ホルクロルフェニュロンによる雨除け 栽培トマトの放射状裂果の発生抑制. 近畿中国四国農業研究 20: $29-31$.

渡辺慎一 2006. 低段密植栽培による新たなトマト生産. 野菜茶研 集報 3: 91-98. 